Faculty of Education

Journal of Education

$* * *$

\title{
Using a VAKT Based Program to Develop EFL Primary Stage Dyslexic Pupils' Reading Skills
}

\section{BY}

Dr. Nahed Mohammed Mahmoud Ghoneim

Professor of Curriculum and Methods of Teaching English,

Faculty of Education, Menoufia University, Egypt

\section{Dr. Heba Elsayed Abdelsalam Elghotmy}

Assistant professor of Curriculum and Methods of Teaching English, Faculty of Education, Menoufia University, Egypt

Receipt date: 1 February 2021 - Date of acceptance: 1 March 2021 


\section{Abstract}

The current research aimed at improving EFL Fifth grade dyslexic pupils' reading skills (Phonemic Awareness -Reading Accuracy- Spelling Reading Comprehension) through using a VAKT based Program. Forty dyslexic pupils enrolled in the fifth year, Primary stage, Menoufia governorate, Egypt were the participants of this research. Data collection was based on a sequential mixed methods approach. The qualitative phase is represented by the semi-structured interviews conducted with EFL primary stage teachers dealing with dyslexic pupils. Based on interviews' responses, a VAKT program was proposed to be used in an EFL reading class. An EFL Reading test was designed by the researchers to be used as a pre-posttest. Data obtained was statistically analyzed. Findings revealed that using the VAKT based program was effective in developing EFL fifth grade dyslexic pupils' reading skills.

Keywords: VAKT based Program - EFL Reading Skills - dyslexic Primary stage pupils. 


\section{إستخدام برناهج قائم على VAKT لتطوير ههارات القراءة لدى التلاميذ الذين يعانون هن عسر القراءة في المرحلة الابتدائية}

ملخص

يهدف البحث الحالي إلى تطوير مهارات القراءة لدى تلاميذ المرحلة الابتدائية الذين يعانون من عسر القراءة (الوعي الصوتي - دقة القراءة - الفهم القرائي - التهجئة) من خلال

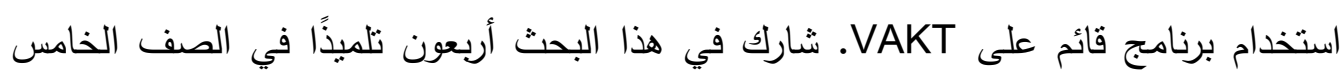

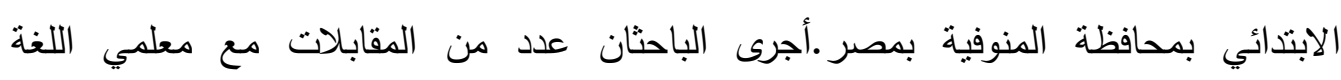

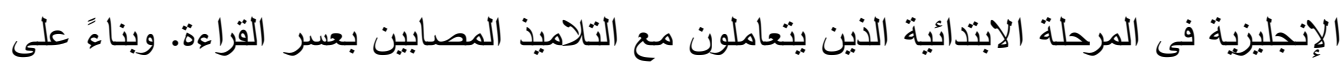

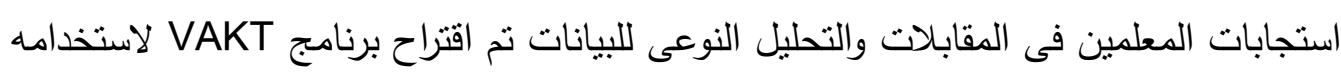
في تتمية مهارات القراءة باللغة الانجليزية. كذلك صمم الباحثون اختبار قراءة باللغة الإنجليزية

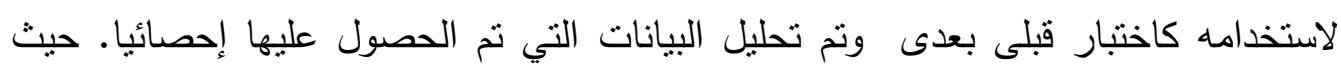
أظهرت النتائج أن استخدام برنامج VAKT كان فعالاً في تطوير مهارات القراءة لاى تلاميذ الصف الخامس الذين يعانون من عسر القراءة في اللغة الإنجليزية.

الكلمات المفتاحية: برنامج - مهارات القراءة باللغة الانجليزية - تلاميذ المرحلة الابتدائية الذين بعانون من عسر القراءة. 


\section{Introduction}

Reading experts at the beginning of the twentieth century have debate about the most effective interventions to enhance reading skills, in particular for learning disabilities' pupils (Anderson \& Fenty, 2013; Griffiths \& Stuart, 2013; Solis et al., 2012). During the 1990s, the whole-language literacy approach, was adopted by primary education system, although there was very little research to prove its effectiveness (Gillam \& Gillam, 2014).

The whole linguistic paradigm, which emphasizes reading as meaningful, shows that textual meaning is more instrumental in developing literacy skills than phonological instruction (Gillam \& Gillam, 2014; Rasinski, Rikli, \& Johnston, 2009). The whole linguistic approach requires the use of a structured academic hierarchy of frameworks that require background knowledge to help students achieve their literacy skills (Altemeier, Abbott, \& Berninger, 2008; Anderson \& Fenty, 2013; Morrow, Gambrell, \& Duke, 2011; Rasinski et al., 2009). Students with disabilities do not benefit greatly from full language instruction, mainly due to their lack of emphasis on phonics and the lack of a structured approach to language learning(Eide \& Eide, 2011; McCulley, Katz, \& Vaughn, 2013; Slavin, Lake, Chambers, Cheung, \& Davis, 2009).

In contrast, explicit and systematic VAKT (visual, audio, dynamic, tactile) learning is more promising for pupils with learning disabilities. The International Dyslexia Association (IDA), The National Institute of Child Health and Human Development (NICD), and The National Reading Group (NRP) argued that VAKT should be used in the primary((IDA), 2019; Adlof \& Hogan, 2018; McIntyre \& Hulan, 2013).

One of the strengths of VAKT is the cognitive neuroscience research that it has developed and led, for example, acoustic impairment as a result of deficits in phonology and short-term memory deficits in the oral domain((IDA), 2019; Adlof \& Hogan, 2018; Goswami, 2008, 2013; Ramus, 2004). VAKT's instructional approaches are distinct considering the cognitive sides which are often found in children with disabilities. Through VAKT teaching, when all learning channels are integrated simultaneously, the skills and process information taught to pupils with learning disabilities are most effectively retained (McIntyre \& Hulan, 2013; Slavin et al., 2009). VAKT instructional methods can be very helpful for pupils with learning difficulties as they focus on a sequence 
of learning and allow academic advancement where instruction is both synthetic and analytic (Birsh, 2005; Kerker \& Birch, 2011; McCully et al., 2013). Diagnostic measures to teaching approaches are implemented using a scope that is relevant to students' learning needs and based on the individual needs of the learner (Birsh, 2005; Karecker \& Birsh, 2011; Gillam \& Gillam, 2014; McCullie et al., 2013).

\section{Diagnosing dyslexic pupils}

The researchers of the study administered School Age Dyslexia Screener (CLDQ): Colorado Learning Disabilities Questionnaire Reading Subscale (CLDQ-R) screener to diagnose pupils with dyslexia and determine the risk level of dyslexia (Willcutt et al., 2011). Willcutt et al. (2011) found that the CLDQ-R was reliable and valid in examining dyslexia risk for pupils. It ia a screening tool for teachers where they asked to read each statement and decide how well it describes their pupils, then, they should circle the appropriate number indicating their answer and add up the circled numbers to record the total score. The screener (Appendix A) was developed by the Colorado Learning Disabilities Research Center (NICHD 027802); Anne Arnett MA and Eric Aune MA helped develop the online versions((IDA), 2018).

\subsection{Context of the Problem}

The problem of the current research is derived from the following resources:

First, previous studies (IDA) (2019); Adolf and Hogan (2018); Colenbrander, Ricketts, and Breadmore (2018); Farrell (2013); Hebert, Kearns, Hayes, Bazis, and Cooper (2018); Schiff and Joshi (2017); (Stage \& Davis, 2004) assured that readers with dyslexia are more likely to experience difficulties in expressive language skills, phonological skills including phonemic awareness, inability to pronounce letters and names quickly or read isolated word lists and contextual words. Furthermore, previous Egyptian studies (Elbeheri \& Everat, 2006; Leicester, Lalont, \& Rep., 2014) pointed out that primary stage dyslexic students had difficulty recognizing English phonemes that do not found in their language phonology.

Second, a pilot study was conducted to confirm, document and determine the problem on a factual and scientific basis. The researchers administered an EFL reading test to the pupils diagnosed with dyslexia and enrolled in an official language school during the first semester of 
the 2020-2021 school year. Findings revealed the apparent weakness in dyslexic pupils' EFL reading skills.

\subsection{Questions of the study:}

The current research attempted to answer the following key question:

How effective is a suggested VAKT based program in developing 5th grade dyslexic pupils' EFL reading skills?

Out of this fundamental question, the accompanying sub questions are stated:

1-What are the EFL reading skills needed for primary stage dyslexic pupils?

2-What are the VAKT program suggested features?

3-To what extent is the suggested VAKT program effective in developing 5th grade primary dyslexic pupils' EFL Phonemic awareness skills (Segmenting, Rhyme, Blending, Onset and rime)?

4-To what extent is the suggested VAKT program effective in developing 5th grade primary dyslexic pupils' EFL reading accuracy skills (Sight word efficiency, Decoding efficiency)?

5-To what extent is the suggested VAKT program effective in developing 5th grade primary dyslexic pupils' EFL reading comprehension skills?

6-To what extent is the suggested VAKT program effective in developing 5th grade primary dyslexic pupils' EFL spelling skills?

\subsection{Hypotheses of the study}

1) There is a statistically significant difference between the mean scores of the pre-test and those of the posttest of the study group on the overall reading skills in favor of the posttest.

2) There is a statistically significant difference between the mean scores of the pre-test and those of the posttest of the study group on the phonemic awareness skills (Rhyme, Onset and rime, Blending, Segmenting) in favor of the posttest.

3) There is a statistically significant difference between the mean scores of the pre-test and those of the posttest of the study group on the reading accuracy skills (Sight word efficiency, Decoding efficiency) in favor of the posttest.

4) There is a statistically significant difference between the mean scores of the pre-test and those of the posttest of the study group on the spelling skills in favor of the post test. 
5) There is a statistically significant difference between the mean scores of the pre-test and those of the posttest of the study group on the reading comprehension skills in favor of the posttest.

\subsection{Aim of the study}

The current research aimed at developing $5^{\text {th }}$ grade primary dyslexic pupils' EFL reading skills through using a suggested VAKT program.

\subsection{Significance of the study}

This research could be significant to:

a. Fifth grade primary dyslexic pupils as the proposed program utilizes intriguing stories, stories and pictures in a way that could develop their reading skills in an attractive manner. utilizes intriguing stories, melodies and pictures

b. EFL teachers as the proposed program offers a new intervention and effective devices to develop their pupils' language skills in general and reading skills.

c. Curriculum planners as it draws their attention to the efficacy of the VAKT instruction to EFL teaching and incorporates some VAKT activities in the English curriculum.

d. EFL researchers with a theoretical foundation that can build on for further research in developing the learning skills in various fields and different stages.

\subsection{Delimitations of the study}

This research was delimited to

1. The VAKT based program proposed by the researchers to develop the participants' EFL reading skills.

2. A group of forty fifth year primary dyslexic pupils, enrolled in primary school in Shebin Elkom, Menoufia governorate.

3. The first semester of the academic year 2020/2021.

4. Current research skills include: EFL reading accuracy (site word efficiency, phonetic decoding), phonological awareness (rhyme, onset, blending, and segmenting), reading comprehension and spelling skills.

\subsection{Operational Definition of Terms}

The VAKT instruction is defined operationally as presenting all information to pupils through sensory particular modes: visual, auditory, kinesthetic, and tactile. Visual presentation techniques include graphic organizers for reading development and images to reinforce teaching, 
whereas auditory presentation techniques include thorough discussion, reading aloud, manipulating blocks, and reading paragraphs. Besides, kinesthetic, and tactile modalities refer to the use of motion and touch activities that enhance the meaning of the reading passages.

\section{EFL Reading skills}

EFL Reading skills are operationally defined as the recognition of the individual letters and how these letters form a word not just on an individual level, but as part of a text. It translates printed words into representations such as verbal language and extracts meaning from the written or printed texts. It incorporates reading accuracy, phonemic awareness, spelling and reading comprehension.

\section{Dyslexic pupils}

Dyslexic pupils are those with a learning disability with neurotic origin. It is characterized by difficulties in correct and / or inaccurate word recognition, decoding ability, and poor spelling. These difficulties can be attributed to the inadequacy of the phonological component of language, which is often unpredictable in relation to other cognitive skills, and effective classroom instruction. Secondary outcomes include difficulties in reading comprehension and decreased reading experience, which hinders the development of vocabulary and background knowledge.

\section{Review of Literature}

\section{The Nature of dyslexia}

Dyslexia is a language processing disorder in which pupils with dyslexia experience weakness in one or more areas of language, such as encoding, decoding, phonological awareness, and syntax. To succeed within a Foreign Language, it "needs the use of specifically those language skills in which dyslexics are weak in their language" (Arries, 1999, p. 1). Dyslexia has been defined by researchers as a problem that makes learners in spite of their classroom experience, have difficulties to read, write, and spell in keeping with their cognitive ability"(Ott, 1997, p. 2).

\section{Symptoms of Dyslexia}

Dyslexia is a language-based learning disorder that has so many symptoms and features that can be difficult to accurately understand its symptoms. However, some frequent characteristics of Dyslexia can be identifed as follows:

it is a disease in which one is born, and it is more common in men than 
in women with genetic and neurological basis. (Ott, 1997, p. 5).

Dyslexics has problems processing one or more features of the language. As seen in dyslexic persons, some areas suffer more than others. When learning to read, the dyslexic person can clearly see which parts of the language are causing the most problems. Reading can be divided into segments; phonology, semantics, orthography or the meaning of words, how to pronounce and write words and letters (Stage \& Davis, 2004; Vaisman \& Kahn-Horwitz, 2019; Wu, Barquero, Pickren, Barber, \& Cutting, 2020).

\section{Dyslexia and foreign language reading}

Since dyslexia influences a person's capacity to handle language, it can surely appear contrastingly relying upon the language expressed. For instance, the issue of phonetic awareness may not be an issue for the individuals who communicate in a transparent language, for example, Spanish, yet it is perhaps the most well-known issues in less transparent languages like English (Lundberg, 2002; Tofalini, Locito, Zamberlin, \& Cornoldi, 2018). In transparent languages, there is a direct connection between graphemes and phonemes. Nonetheless, dyslexics who communicate in these languages may experience issues with motor-skills, word retrieval or even with their short-term (Lundberg, 2002; Miller-Krone \& Lundberg, 2000).

Dyslexics have commonly been appeared to have no problems with reading semantic aspects, as they are typically within normal range (Snolling, 2007). Because their lack of phonological awareness, they have difficulties in the orthographic and phonological reading aspects (O'Brien, Mohamed, Yussof, \& Ng, 2018). Phonology is an important component of language instruction. Phonetic awareness is understanding that individual graphemes are straightforwardly associated with a specific phoneme.

Because of this imbalance, dyslexics have difficulty reading, especially when confronted with non-words that they cannot understand their meaning in context. Problems in dyslexics are also found when reading, as it requires phonological-orthographic relationship understanding (Cain \& Oakhill, 2006; Colenbrander et al., 2018). To articulate a word accurately, one should initially hear various sounds and afterward relate it to a given grapheme and record it on paper. Different symptoms generally seen in dyslexia include difficulties with verbal naming and recovering speech (Kang \& Shin, 2019; Layes, 
Lalonde, \& Rebaï, 2014). Processing language information can be time consuming due to short-term memory, mental or memorization problems, rhythm, motor skills, auditory and visual perception and sequencing language difficulties, and problems that lead to poor handwriting (Everatt \& Reid, 2009; King, Giess, \& Lombardino, 2007).

\section{Reading errors characteristic for developmental dyslexia}

Most often the errors in reading committed by dyslexic students are concerned with:

1. Experiencing difficulties remembering the sound corresponding to a letter being read,

2. Not distinguishing between letters that have similar shape, e.g. p$\mathrm{d}, \mathrm{d}-\mathrm{g}$,

3. Reading words backwards, especially short ones, e.g. god-dog, saw-was,

4. Reading the first and the last syllable, skipping the syllable/s in the middle,

5. Skipping words,

6. Losing the pace of reading,

7. Skipping lines,

8. Reading the same line again

9. Skipping the beginnings or endings of words,

10. Guessing words on the basis the first letter, syllable, or the global 'picture' of the word,

11. Slow reading or fast but imprecise reading,

12. Long breaks before attempting to read a difficult word,

13. Not using proper intonation and punctuation,

14. Difficulties with or lack of understanding the text,

15. Understanding a new sentence structure (past / present / future tensions, word order in a sentence, etc.).

\section{The VAKT approach}

Sending different information to the brain in different sensory channels (visual, auditory, tactile, kinesthetic etc.) facilitates the storage and playback of information, and therefore the learning process. Offering multi-sensory activities increases the effectiveness of teaching and learning, for students with dyslexia (Prasetyaningrum \& Faradila, 2018). Of concern to them is the use of movement as part of the learning process in general and language learning. Associating language with a certain movement, and therefore the association of a linguistic 
element with specific action leads to wider multidimensional and stable mental image of this element and its absorption(Erdely-Bartha, 2017).

VAKT instruction system have developed a leading training practices to meet the needs of 21 st century academic skills, which enhances the achievements of dyslexic students.

The No Child Left Behind Act considered explicit phonics programs to be a potential requirement under the Reading First program, which was grounded on incorporating scientifically based reading programs using teaching methods that have been validated (Evans \& Hornberger, 2005; Lee, Sullivan, \& Gupta, 2011). These directives aimed at prioritizing education by reforming standards in literacy (Halladay \& Duke, 2013; Strickland, 2013).

\section{Implicit versus Explicit Phonics}

Discussions are going on the best reading programs and approaches which are most effective for dyslexia pupils' achievement (Cain \& Oakhill, 2006; Halladay \& Duke, 2013; Ransby \& Swanson, 2003; Rasinski et al., 2009; Snowling, 2007; Toffalini, Losito, Zamperlin, \& Cornoldi, 2018). As a result, approaches to reading instruction are divided between explicit and implicit phonics instruction. In an implicit phoenix instruction, learners are expected to evoke sounds that are consistent with the auditory information collected and the visual exposure to words that contain the letters(Clark, 2013; Mitchell \& Sutherland, 2020).

This approach differs from explicit phonics, because VAKT procedures are compatible with clear instructional methods that directly teach pupils sound-symbol correspondence for individual phoneme segments (Prasetyaningrum \& Faradila, 2019). This approach provides pupils with code for developing word systems (Wise \& Goswami, 2008). Beck and Beck (2013) argued that indirect phonics instruction barriers are caused by pupils' lack of direct skills in recognizing sounds in words due to difficulties in sound segmentation or the process of isolating sounds within words. Therefore, the implicit phonics instruction does not support VAKT instructional practices (Bowers, 2018; Ehri, Nunes, Stall, $\&$ Willows, 2001). The central component of VAKT teaching methods focuses more on explicit phonics (Prasetyaningrum \& Faradila, 2018). This kind of instruction is defined, developed and designed for pupils with reading difficulties. 
Explicit instruction is defined as "teaching in which the soundspelling relationships are directly taught"(Blevins, 2003, p. 1). Additionally, this type of instruction is systematic because it follows a direct sequence where skills are consistently reviewed and integrated into texts (Blevins, 2003). Research indicates that explicit instruction is most successful for dyslexic pupils who have reading problems (Birsch, 2005; Carreker \& Birsh, 2011; Hatcher, Hulme, \& Snowling, 2004; Lonigan, Burgess, \& Anthony, 2000; O'Brien, Mohamed, Yussof, \& Ng, 2018; Ransby \& Swanson, 2003).

Explicit phonics allows dyslexic pupils to use the phonemic decoding skills needed to decode words, and it allows them to understand the relationship between letters and sounds (Bowers, 2018; Wyse \& Goswami, 2008). This type of correspondence between phonemes and graphemes are the basic skills that are needed in explicit phonics to identify the relationship between sound-symbol correspondences in words (Blevins, 2000; Phajane, 2014).The goal of explicit phonics for dyslexic pupils is to be able to decode words both in isolation and in text reading following the application of letter-sound correspondence(Schiff \& Joshi, 2017; Tarrasch, Berman, \& Friedmann, 2016). Explicit phonics is important for achievement for dyslexic pupils who exhibit core phonological deficits (Thompson, 2015). Therefore, VAKT structured language programs, developed by the International Dyslexia Association, calls for explicit programs of instruction rather than implicit ones((IDA), 2018). Research indicates that a VAKT structured language curriculum should include specially designed content and principles of instruction that embed visual, auditory, kinesthetic, and tactile modalities((IDA), 2018, 2019; Liptak, 2016). Reading is particularly important for pupils who exhibit learning disabilities, specifically because $75 \%$ to $80 \%$ of pupils who exhibit learning difficulties have reading problems((NCLD), 2014; Turner, Clabough, \& Cole, 2014, p. 78).

\section{Phonemic awareness}

Phonemic awareness is an important component of reading instruction as it is the ability to manage phonemes, or speech sounds, in syllables and words(Schiff \& Calif, 2007; S. E. Shaywitz \& Shaywitz, 2007, 2008). Research indicated the strong relationship between phonemic awareness and success in reading and spelling acquisition (Hatcher, 2006; Kang \& Shin, 2019; Layes et al., 2014; O’Brien et al., 2018; Schiff \& Calif, 2007). The goal of early literacy development is to 
understand the alphabetic principle and master identifying words. This alphabetic principle is based on the relationship between letters and sounds. Sound-symbol correspondence is a basic skill for pupils to master prior to progressing to word recognition skills (Carreker \& Birsh, 2011; Ransby \& Swanson, 2003; Wu et al., 2020).

Ehri, Nunes, Stahl, \& Willows (2001) evaluated the effectiveness of systematic explicit phonics instruction in comparison to unsystematic inexplicit phonics instruction in grades ranging from kindergarten to sixth grade. The results of this study demonstrated that "systematic phonics instruction helps children learn to read", emphasizing the importance of embedding VAKT, explicit and systematic phonics instruction to prevent reading difficulties, especially for pupils at risk in reading ( Ehri et al., 2001, p. 393).

\section{Phonics}

The second central component of reading instruction is phonics. Skilled readers can blend, and segment sounds within words as they understand the representation of phonemes; they do not have to rely on memorization to retrieve words accurately (Thompson, 2015; Wyse \& Goswami, 2008). The (NRP) (2000) stated that phonics difficulties served as the key factor for hindering success in oral reading fluency. The panel has proposed a VAKT instructional paradigm for teaching encoding, decoding, and comprehension that supports phonics-based instruction ( Ehri et al., 2001).

\section{Fluency}

The third central component in reading instruction is fluency. Advancing from phonics to fluency, Shaywitz (2003) assures the importance of "training the brain" (p. 268) by using phonetic-based programs that are explicit and systematic. Feedback, guidance, and instruction principles are important elements that must be included in a VAKT program to build students' fluency skills (Shaywitz, 2003). Tolman (2005) further emphasized the importance of teaching fluency acquisition as early as kindergarten. Explicit instruction plays a significant role in pupils' abilities to develop reading fluency skills (Hatcher et al., 2004; Thompson, 2015).

\section{Vocabulary}

Vocabulary is the fourth central element of reading instruction. Vocabulary is a skill that is taught directly and indirectly to pupils in primary grades by exposure through print (NRP, 2000). Dyslexic pupils 
require repeated exposure to read aloud books, in person, or on tape to gain access to higher-level vocabulary word acquisition. Vocabulary instruction must include presenting vocabulary in varying contexts, direct explanation of vocabulary words, and indirect print exposure (NRP, 2000). Furthermore, the NRP (2000) argued that the use of explicit instruction in rich and powerful contexts, incidental learning, and the use of digital technology have the potential to enhance dyslexic pupils' vocabulary skills. Vocabulary skills are important for reading comprehension skills; therefore, pupils generally require multiple methods of teaching to acquire vocabulary concepts easily (NRP, 2000).

\section{Reading comprehension}

The fifth element is reading comprehension which is essential for pupils to gain meaning from connected text reading, and it is especially important for those who have learning impediments (Ali, 2012; C. Ehri et al., 2001; McCulley et al., 2013; Tarrasch et al., 2016; Toffalini et al., 2018). To master the comprehension reading process, pupils need to be able to decode words with fluency and accuracy (Kang \& Shin, 2019). The NRP (2000) stressed the importance of combining metacognitive techniques to facilitate the acquisition of reading comprehension, including generating, answering, and summarizing information. Torgeson (2002) stated that reading with comprehension requires two elements: (a) general language comprehension; and (b) the ability to accurately and fluently decode words in print. Tolman (2005) further argued that special attention must be given to pupils who do not learn to decode as they are typically at-risk for low vocabulary and comprehension skills.

The recommendations of the NRP (2000) have been fundamental with regard to providing instructional practices that are research-based and support VAKT, explicit, and systematic teaching practices that focus on phonics, phonemic awareness, vocabulary, fluency, and comprehension. Langenburg (2000) added that pupils at risk for reading failure need direct and systematic instruction in these skills. Additionally, adopting the recommendations of the NRP by developing a VAKT matrix that focused on the five vital elements of literacy acquisition(Moats et al., 2014). Consequently, VAKT, explicit, and systematic teaching practices are parallel to the five essential elements for reading; phonemic awareness, fluency, phonics, vocabulary, and 
reading comprehension(Erdely-Bartha, 2017; Prasetyaningrum \& Faradila, 2019).

\section{Methodology}

The present research follows a sequential exploratory descriptive mixed-method design (Tashakkori \& Teddlie, 2010). The researchers first conducted the qualitative phase of the study, followed by a quantitative one; this permits researchers to elaborate on the assumptions of the paradigm behind each stage (Creswell, 2013).

\section{The First phase}

Interviews are used to fully explore participants' opinions about a topic, according to Cohen, Manion, and Morrison (2005); to give researchers an in-depth view of the research phenomenon under investigation; agree or disagree with previously formulated theories about participants' views. Researchers have designed interview questions (Appendix B) to provide lengthy answers that allow for purposeful conversations guided by themes and topics, allowing them to be considered, rearranged, discussed, and analyzed.

\section{Semi- Structured Interviews Method}

This research uses interview to compare current theories about dyslexia and to compare real life situations EFL teachers encounter when dealing with dyslexic pupils in their classrooms. It analyzes teachers' information on dyslexia and their instructing procedures to check whether they are viable with current standards for teaching dyslexic pupils. A qualitative research interview is an endeavor to comprehend the world from the subjects' perspectives, to unfurl the significance of their encounters (Quayle 2008). By interviewing teachers, it is hoped that it shows their thoughts on dyslexia, the difficulties they encounter when working with these pupils and what they have found to be most effective.

\section{Participants}

Six female EFL teachers (teacher A-F) were interviewed. The Teachers have worked at various levels in the field of education for different amounts of time. This gives the investigation a more extensive scope of perspectives. The various periods of time additionally influence the number of deslexic pupils that every teacher had instructed. This, obviously, influences how teachers can talk about the issue. Interviews were done with small groups of teachers empowering a more open conversation about dyslexia and teachers were ready to 


\section{share their own perceptions.}

\section{Ethical aspects of interviews}

Teachers who came to the interview were informed about the purpose and practice of the interview before agreeing to the interview. They were told that their answers were being recorded for better analysis. All teachers consented to the interview and were eager to join in. All interviews were recorded on a PC to be transcribed and interpreted later.

\section{Data coding and categorization}

Each meeting group was interviewed for a normal 60 minutes. Interview questions were about teachers ' knowledge, their own experience with dyslexic puipls, and how they work with them. To proceed with the progression of the conversation, the arrangement of questions was moved starting with one group then onto the next, and some new questions were posed during the meeting. Interviews were then interpreted verbatim and later used as the base of the study's investigation. To look at the teachers' responses, a categorization approach was utilized. Every interviewee's answers were set into a a created category that can be effortlessly used to see patterns existing in the interviewee's answers.

\section{Reliability}

Reliability was tested in two stages: first, through data coding and second, through data analysis and categorization. In terms of coding, it is intended to ensure that the codes are structurally compatible and that they are meaningfully related and different from others. Check-coding of transcripts was also useful to verify authenticity.

This is done in two ways: first, by coding twice at two unique occasions; second, asking a colleague in the similar field to code two interviews to check whether he/she can dole out similar codes to similar sections of information. The researchers utilized similar codes to check the representation of similar pieces of data. On account of agreement, a tick $(/)$ is put and for disagreement a cross $(\mathrm{x})$ is set. The reliability coefficient between both the second rater's coding and the researchers was determined to guarantee that all the codes fit into one structure. The estimated inter-rater agreement is $82 \%$. The operational definition of codes is additionally settled upon with a consequence of $87 \%$. 


\section{Results and Discussion}

\subsection{Qualitative Data Analysis}

Three main themes were constructed as revealed by qualitative data analysis to include:

The way teachers describe dyslexia, the difficulties EFL teachers have when teaching dyslexic pupils, and the strategies EFL teachers use when teaching a dyslexic pupil. Comments frequently differed, mirroring the exceptional experiences of every participant.

\section{The first theme: The way EFL teachers describe dyslexia}

Most of teachers thought that it was hard to give a meaning of dyslexia and were uncertain of what this disorder is. interviewed teachers ' answers could be split into two primary groups; symptoms and consequences. Teachers $(\mathrm{C}, \mathrm{D}, \mathrm{E}$, and F) said that dyslexic students experienced issues perusing, learning new words and spelling. They additionally said that those pupils took more time finishing tasks, handily stirred up similar letters, for example, [b] and |[d], and didn't comprehend the connection among graphemes and phonemes. These teachers additionally defined dyslexia as a disorder related with the brain, influencing an individual's capacity to understand language.

[...] now and again it's reading, in some cases

it's the spelling, it's that they need phonetic

\section{awareness.}

\section{Teacher B}

The interviewed teachers characterized dyslexic pupils as individuals who, for instance, experiences issues in reading, incorrectly spells words, and needs structure in their reading. Despite the fact that, many of the teachers concurred that dyslexic pupils frequently had reading difficulties.

This is even more difficult if the teacher does not know why a pupil has more difficulty reading the words in the textbook. If teachers were unaware that this problem was brought about by a lack of phonetic awareness, they would not be aware that this pupil need extra help to hear, say, and read letters.

Teachers also found that dyslexic pupils mispronounced words by either excluding silent letters or reading the letters out of order. Instructor D depicted dyslexia and poor reading skills as follows: 
[...] Dyslexic pupils may have difficulty figuring out how to start a sentence

\section{Teacher D}

Educators additionally saw that their dyslexic pupils required more opportunity to deal with what they were going to say in the EFL. Teacher F explained how dyslexic pupils who usually do reading tasks cannot say a word in EFL when asked in class. She describes:

You may find that it is difficult for the best pupils to

improve their language because what they are

doing was spending more time and energy on reading tasks. - Teacher $F$

Teacher B, Teacher C and Teacher D accepted that all of the dyslexics they had worked with appeared to be all the more involved during hands on activities. The entirety of the teachers tried to see their dyslexic pupils to be more, "responsive" (Teacher D) during sensory activities, for example, when listening to audio books, music, or the teacher's presentations before the class.

The second theme: The difficulties EFL teachers have when teaching dyslexic pupils

All teachers believed that dyslexic pupils should be treated differently than non -dyslexic ones. Apart from one, they had difficulty figuring out how to best help these pupils consistently, and often asked about what to do first (Teacher F). The teachers believed that dyslexic pupils could achieve the same goals as non-dyslexic pupils or learn to read the language. Teacher $\mathrm{C}$, who accepts that dyslexia ought not be viewed as a boundary, clarified:

I don't think this is an imperfection. This is

something you need to manage. As you

probably are aware, this isn't a problem, yet another way of learning.

Teacher $B$

Instructor $A$ felt that her dyslexic pupils might not have similar prospects to become familiar with EFL as a non-dyslexic pupil yet considered English to be gainful for all pupils. She stated: 
I actually feel that language learning grows the minds of dyslexic pupils. It gives them an overall information on another culture. It enhances their knowledge-Teacher $C$

Dyslexia is a disorder affecting pupils' reading skills language processing skills. EFL learning included as a difficult area for dyslexic pupils since it depends on an individual's capacity to comprehend and utilize a language. Hence, it isn't amazing the teachers interviewed found that dyslexic pupils regularly had issues when reading in EFL. This, in turn, influences the EFL teacher's ability to teach the pupils.

The third theme: The strategies EFL teachers use when teaching a dyslexic pupil

Teachers $\mathrm{D}, \mathrm{E}$ and $\mathrm{F}$ felt that more time was needed to implement strategies that would help dyslexic pupils. The assessment was very disappointing as the A, B and $\mathrm{C}$ teachers didn't have a clue how to group dyslexic pupils without being unjustifiable to other pupils. Instructor A communicated dissatisfaction at the manner in which dyslexic pupils were dealt with uniquely in contrast to non-dyslexic ones by saying:

[...] We have to take care of dyslexic pupils, they are weak, they suffer, we have to think about them.

\section{Teacher C.}

The teachers' strategies were: abbreviate the task, give the pupils additional time, and orally retell what they have reading to the teacher to clarify what they have reading, use recordings, pictures, and music to teach new words and verb conjugations.

I permit dyslexic pupils to work with non-dyslexic ones, by reading the word on various occasions, by replicating information and words straightforwardly from the reading material, and by making power-point presentations that pupils can see in class and furthermore utilizing recordings, pictures and music.

Teacher $B$ and Teacher $F$.

Most of the teachers agree that songs and visual images have been shown very effective with dyslexic pupils in reminding them how to conjugate a verb. 


\subsection{Quantitative Data Analysis}

\section{Participants of the research}

The sample consists of 40 fifth grade primary stage dyslexic pupils enrolled in Al Shahid Khaled Allam primary School, Meet Khaqan, Shebin Elkom, Menoufia Governorate.

Instruments and Materials of the research

1. An EFL Reading Skills Checklist.

2. An EFL reading skills pre-posttest.

3.A reading comprehension skills rubric.

4.A VAKT based program.

These instruments and materials are presented in detail as follows:

\section{The EFL Reading Skills Checklist}

The purpose of the reading Skills checklist

The Reading skills checklist was designed to determine the reading skills that are relevant to the fifth-grade primary school dyslexic pupils.

Sources of the Reading skills checklist

Constructing the checklist was based on reviewing:

a. The textbook of English for fifth grade primary school pupils "Time for English".

b. The Teacher's Guide for "Time for English" for primary school.

c. The Ministry of Education Directives for general primary school teachers (2020-2021).

d. The related literature and previous studies concerning EFL Reading skills.

\section{Validity of the EFL Reading Skills checklist}

The checklist was submitted to a panel of jury members (including faculty members of EFL in faculties of Education, some supervisors, and senior teachers of EFL in the primary stage) to validate it. The jury members validated the instrument and provided some comments that were considered by the researchers who modified and refined the checklist accordingly. The juries were requested to determine the suitability of each sub-skill to the reading level in which it is classified. Some of the comments and remarks given by the jury members were as follows:
a. Combining some sub- reading skills together.
b. Including some new skills related to VAKT.
c. Omitting some unsuitable reading sub skills. 
The final version of the checklist consisted of 9 main skills and 37 sub skills (Appendix C).

\section{The EFL Reading skills pre-posttest:}

\section{Aim of the pre-post reading test}

To investigate the effectiveness of the VAKT learning -based program in developing the identified reading skills, there was a need for exposing the pupils to a reading test before and after implementing the program.

\section{Description of the test}

The identified reading skills were used in constructing the test to be used as a pre-posttest. The test consisted of 15 questions. The following table of specifications shows the emphasis given to each skill. Table (1)

The Specifications of the EFL Reading skills pre-post Test

\begin{tabular}{c|c}
\hline Items No & Measured skills \\
\hline $1,2,3,4 \& 5$ & Sound and word discrimination \\
\hline $6 \& 7 \& 8$ & Rhyming \\
\hline $6 \& 9$ & Blending \\
\hline 10 & Segmenting \\
\hline $11,12 \& 13$ & Sight word reading \\
\hline $4,5,11,12 \& 13$ & Decoding \\
\hline 14 & Comprehension \\
\hline 15 & Spelling \\
\hline
\end{tabular}

\section{Validating the Test}

The validity of the test was measured in two ways: Face validity, content validity and comparison of extreme groups. Face validity means the validity at face value. This aspect of validity refers to whether or not the test looks reasonable. As a check on face validity, test items are judged by the panel of jury to obtain suggestions for modification. Content validity indicates that knowledge and skills covered by test items represent a large domain of knowledge and skills required.

To determine both face validity and content validity of the Reading Pre-posttest, the test was submitted to a panel of jury, comprising faculty members in TEFL and some experts, supervisors, and teachers of EFL in the primary stage. They were requested to read the test items and give their opinions as to the following: 
1. To what extent the test items are appropriate and sufficient to measure the EFL reading skills required for the research?

2. To what extent the test items are appropriate for the fifth primary school pupils' abilities?

Some valuable remarks were provided, and then taken into consideration. Modifications were made. The final version of the test is shown in Appendix D

\section{Reliability of the Reading Pre-posttest}

\section{Test-retest method:}

To estimate the reliability of the test, a pilot research of the Reading Skills pre-post test was conducted at the beginning of the second term of the school year 2020 on a randomly selected group of fifth year primary school pupils $(\mathrm{N}=40)$ other than those participating in the current research. They were retested after two weeks from applying the pre-test, and then the researchers used cronbach's alpha correlation to estimate the reliability of the test. The cronbach's alpha correlation showed a high correlation coefficient (Cronbach's alpha=0.91).

Table (2)

Reliability of the components of the EFL reading skills test

\begin{tabular}{c|c}
\hline Sub-skills & Cronbach's Alpha if Item Deleted \\
\hline Phonemic awareness & 0.81 \\
\hline Reading accuracy & 0.89 \\
\hline Spelling & 0.88 \\
\hline Reading comprehension & 0.80 \\
\hline
\end{tabular}

overall EFL Pupils' Reading Skills Cronbach's Alpha=0.87

\section{Inter- rater reliability}

Inter-rater reliability is used to determine the extent to which different raters/observers give consistent estimate of the same phenomenon.

To avoid the subjectivity factor in grading the Reading test, two raters were asked to measure the reliability of the Reading pre-posttest using the rubric prepared by the researchers. Calculating the relation between the two applications indicated that $r=0.87$.

\section{Internal consistency}

Internal consistency measured using the correlations between different skills and the total sum of the test. 
Table (3)

Internal consistency of the pre-post reading test

Sub-skill

Phonemic Awareness

Reading Accuracy

Spelling

Reading Comprehension overall EFL Pupils'

Reading Skills

$0.87^{* *}$

$0.83^{* *}$

$0.89^{* *}$

$0.81^{* * *}$
Sig

Significant at

(0.01)

Significant at

(0.01)

Significant at

$(0.01)$

Significant at $(0.01)$

${ }^{* *}$ Correlation is significant at the 0.01 level

Table (3) indicates correlation between the nine skills and the total sum of the test score. All correlations found to be statistically significant. This shows that the test is internally consistent.

Piloting the EFL reading skills test

To determine the clarity of the test instructions and questions, the test was applied to 40 th year primary school dyslexic pupils not involved in the research to investigate:

a. The clarity of test instructions.

b. The suitability of the test items in terms of the pupils' educational level.

c. The simplicity /difficulty of the test questions to make sure pupils could understand them easily.

d. Test timing.

The piloting helped in estimating the time required for responding to the questions according to the following equation:

The sum of each pupil's time (2000)

Test time $=$

$$
\text { Pupils' number (40) }
$$

Accordingly, the time of the test was (50) minutes.

\section{The EFL Reading Comprehension Rubric}

A rubric was prepared by the researchers to score the participants' responses to the open-ended questions included in the test. The rubric included two levels of the EFL reading comprehension skills. Each level included several sub-skills. The scale consisted of three points: (0) poor, (2) good and (3) advanced. The preliminary version of the rubric was 
submitted to the jury panel to validate it. The jury recommended that more definite words to be used to be able to assess the participants' skills accurately. After making the recommended modifications, the final form of the rubric was shown in Appendix E

\section{VAKT based program}

The VAKT based program is designed to develop some reading skills of EFL fifth grade primary school dyslexic pupils. The program includes the following:

\section{Objectives of the program}

By the end of the program, dyslexic pupils will be able to:

1. Identify the names of letters.

2. Recognize the alphabets in their lower and upper case.

3. Discriminate words having the sounds in initial, medial, and final positions.

4. Discriminate between long and short vowels.

5. Pick up words that rhyme.

6. Orally blend syllables or onset-rimes.

7. Orally blend separate phonemes into a whole word.

8. Reorder letters of words in accordance to their sounds.

9. Divide words into sounds.

10. Count the numbers of letters and sounds in the given words.

11. Read regular 1-syllable words fluently

12. Read regular multisyllabic words.

13. Use silent consonants (e.g., kn, gh).

14. Recognize some words by sight.

15. Write letter associated with each sound in1-syllable, phonetically regular words.

16. Spell single-syllable regular words correctly and independently.

17. Spell phonetically regular words correctly.

18. Answer who, what, when, where, and how questions after reading a paragraph.

19. Tell the main idea of a simple story or the main topic of an informational passage.

20. Identify the main characters, setting, and events.

\section{Description of the VAKT Program .}

It is a program that shows the essential components of reading skills, sounds and letters, and coordinates the technique of combining these sounds and isolating them. This intercession contends that 
elementary school dyslexic pupils should learn the alphabet and phonetics of words.

The VAKT program integrates simultaneously the visual, auditory, and kinetic languages. As they read, pupils will trace the letter, and state the name and sound of the letter. They blend the letters, read words, sentences. Spelling is additionally executed. The program incorporates five fundamental components; teaching letter sounds and formation, blending letter-sounds for reading, identifying sounds for writing, and tricky words spelling. The program offers primary school dyslexic pupils the opportunity to practice a predetermined phonemegrapheme correspondence through reading and spelling.

\section{Duration of the Program}

The program was implemented in the first semester of the academic year 2020-2021. It lasted for two months at a rate of two sessions weekly. Every session lasted for 60 minutes during which the pupils learnt the letter sound correspondences and the basic skills in using VAKT phonics. Pre-testing administered a week prior to the intervention. Post-testing was conducted two weeks period following the interventions. Pre-post-testing was conducted by the researchers.

\section{Instructional Aids}

Videos, puppets, flashcards, printed papers, tape records, colorful sand, Clay, and cubes.

\section{Activities}

\section{Visual}

1. Text, images, posters, models, computers or flash cards.

2 .Use color to highlight and adjust information or images.

3 .The pupils created art, pictures, text, pictures and video.

\section{Auditory}

1. Audio books, computerized books, and peer assisted reading.

2. Audio video films.

3. Songs and language games.

\section{Tactile}

1. Using finger paints and textured objects to enhance pupils' fine motor skills.

2. Modeling games using clay.

3. Use small objects called manipulatives to indicate numeric values to teach mathematical skills. 


\section{Kinesthetic}

1. Jumping rope, clapping, or other movement-related games when thinking and playing.

2. Doing large movement activities such as dancing, bean back tossing or other educational games such as rhythmic recall, quizzes, flash card races and learning games.

Table (4)

Paired Differences between Pre-Post- tests' Scores

\begin{tabular}{|c|c|c|c|c|c|c|c|c|}
\hline \multirow[b]{2}{*}{ Sub-skill } & \multirow{2}{*}{ Test } & \multicolumn{2}{|c|}{ Paired Differences } & \multirow{2}{*}{$\begin{array}{l}\mathrm{t}- \\
\text { Value }\end{array}$} & \multirow{2}{*}{${ }^{2} \eta$} & \multirow[t]{2}{*}{ D.f } & \multirow{2}{*}{\begin{tabular}{|l|} 
effect \\
size d
\end{tabular}} & \multirow{2}{*}{$\begin{array}{l}\text { Significance and } \\
\text { Practical } \\
\text { significance }\end{array}$} \\
\hline & & Mean & S. D & & & & & \\
\hline $\begin{array}{l}\text { Phonemic } \\
\text { awareness }\end{array}$ & $\begin{array}{l}\text { Posttest } \\
\text { Pretest }\end{array}$ & 17.60 & 3.77 & 29.55 & 0.96 & 39 & 9.46 & $\begin{array}{c}\text { Significant at (0.01) } \\
\text { and } \\
\text { educationally } \\
\text { important }\end{array}$ \\
\hline $\begin{array}{l}\text { Reading } \\
\text { accuracy }\end{array}$ & $\begin{array}{l}\text { Posttest } \\
\text { Pretest }\end{array}$ & 5.64 & 2.85 & 12.50 & 0.80 & 39 & 4.00 & $\begin{array}{c}\text { Significant at (0.01) } \\
\text { and } \\
\text { educationally } \\
\text { important }\end{array}$ \\
\hline Spelling & $\begin{array}{l}\text { Posttest } \\
\text { Pretest }\end{array}$ & 1.00 & 0.85 & 7.40 & 0.58 & 39 & 2.37 & $\begin{array}{c}\text { Significant at (0.01) } \\
\text { and } \\
\text { educationally } \\
\text { important } \\
\end{array}$ \\
\hline $\begin{array}{c}\text { Reading } \\
\text { comprehension }\end{array}$ & $\begin{array}{l}\text { Posttest } \\
\text { Pretest }\end{array}$ & 0.99 & 0.08 & 79.00 & 0.99 & 39 & 25.30 & $\begin{array}{c}\text { Significant at (0.01) } \\
\text { and } \\
\text { educationally } \\
\text { important }\end{array}$ \\
\hline $\begin{array}{c}\text { Overall EFL } \\
\text { dyslexic } \\
\text { Pupils' } \\
\text { Reading Skills } \\
\end{array}$ & $\begin{array}{l}\text { Posttest } \\
\text { Pretest }\end{array}$ & 30.63 & 6.69 & 28.94 & 0.96 & 39 & 9.27 & $\begin{array}{c}\text { Significant at (0.01) } \\
\text { and } \\
\text { educationally } \\
\text { important }\end{array}$ \\
\hline
\end{tabular}

According to the results presented in table 4, it is apparent that the differences between the study group's mean scores on the pre-post-tests are statistically significant. Consequently, $96 \%$ of the variations between the scores of the overall EFL Pupils' Reading Skills could be due to the VAKT -based program.

\section{Discussion of the results}

The results might be due to the following reasons:

1) The lessons and activities that were designed by the researcher, the different VAKT tools and actions were used to give the pupils 
more time to interact with the activities under guidance and support of the teacher in a meaningful, positive, peaceful and enjoyable atmosphere.

2) The VAKT learning based program used materials that raised pupils' motivation, interest, and drew their attention by increasing visuality and providing pupils with opportunity for active participation. The pictures and the sounds helped them to understand the lessons.

3) The suggested program concentrates on developing the fifth-grade pupils' ability to segment and blend phonemes in spoken words that were largely enhanced by their exposure to VAKT Phonics instruction.

4) The researcher explored various Multi sensorial tools in reading activities that helped the pupils to develop their EFL reading skills. The researcher used various games and activities which depended mainly on authentic materials to enrich pupils' learning in peaceful enjoyable environment.

\section{Conclusion}

The current research aimed at improving EFL Fifth grade dyslexic pupils' reading skills (Phonemic Awareness -Reading AccuracySpelling - Reading Comprehension) through using a VAKT based Program. Forty dyslexic pupils enrolled in the fifth year, Primary stage, Menoufia governorate were the participants of this research. Data collection was based on a sequential mixed methods approach. The qualitative phase is represented by the semi -structured interviews conducted with EFL primary stage teachers dealing with dyslexic pupils. The researchers designed a pre-posttest EFL reading test for the study purposes. In addition, a VAKT based program was proposed to be used in an EFL reading class. The data obtained were statistically analyzed. The results uncovered a noticed development in the study group's reading skills. It was concluded that the VAKT Based program was effective in enhancing the EFL reading skills of Fifth-year primary school dyslexic pupils. 


\section{Recommendations}

In light of the results of the current study, the following recommendations are suggested:

1. Teachers ought to be provided with specific training programs to use VAKT interactive features to develop other language skills.

2. There should be technical support strategies for teachers who regularly use VAKT programs and activities so that they feel genuinely supported.

3. Teachers' awareness of dyslexics' motivation to apply various strategies should be raised to stimulate their taste for learning.

4. All future teachers should be trained in pedagogical and interactive uses of VAKT programs.

5. Assessment of the uses, benefits, and challenges of VAKT learning in class should be continued.

6. Further action research and case studies on educational integration of VAKT instruction should be conducted. 


\section{References}

(IDA), I. D. A. (2018). Knowledge and Practice Standards for Teachers of Reading. $2 . \quad$ Retrieved from file://C:/Users/Heba\%20Elghotmy/Downloads/FINAL\%20KPS\%20F OR\%20PUBLICATION_May2018.pdf

(IDA), I. D. A. (2019). IDA Dyslexia Handbook: What Every Family Should Know. Retrieved from https://app.box.com/s/8ucxzz2u5wq2wezqoaqgrltn532z97bz

(NCLD), N. C. o. L. D. (2014). The State of Learning Disabilities. 3. Retrieved from https://www.ncld.org/wp-content/uploads/2014/11/2014-State-ofLD.pdf

(NRP), N. R. P. (2000 .(Teaching children to read: An evidencebased assessment of the scientific research literature on reading and its implications for reading instruction: Reports of the subgroups. Retrieved from Washington, DC :

Adlof, S. M., \& Hogan, T. P. (2018). Understanding Dyslexia in the Context of Developmental Language Disorders. Lang Speech Hear Serv Sch, 49(4), 762-773. doi:10.1044/2018_lshss-dyslc-18-0049

Adolf, M., \& Hogan, P. (2018). Understanding Dyslexia in the Context of Developmental Language Disorders. Lang Speech Hear Serv Sch, 49(4), 762-773. doi:10.1044/2018_lshss-dyslc-18-0049

Ali, S. (2012). Teaching Reading and Spelling to Adult Learners: The Multisensory Structured Language Approach. English Language Teaching, 5(3). doi:10.5539/elt.v5n3p40

Altemeier, L. E., Abbott, R. D., \& Berninger, V. W. (2008). Executive functions for reading and writing in typical literacy development and dyslexia. Journal of clinical and experimental neuropsychology, 30, 588-606. doi:https://doi.org/10.1080/13803390701562818

Anderson, E., \& Fenty, N. (2013). Integrating early literacy and other content curriculum in an era of increased accountability: A review of the literature. Advances in Early Education and Day Care, 17, 153-177 .

Arries, J. F. (1999). Learning Disabilities and Foreign Languages: A Curriculum Approach to the Design of Inclusive Courses. Modern Language Journal, 83(1), 98-110 .

Birsch, R. (2005). Multisensory teaching of basic language skills (2nd ed. ed.): Baltimore, MD: Paul.

Blevins, W. (2000). Teaching Phonics and Word Study in the Intermediate Grades.

Blevins, W. (2003). Controlled Text: Does It Really Make a Difference? Paper presented at the The International Reading Association . 
Bowers, S. (2018). Reconsidering the evidence that systematic phonics is more effective than alternative methods of reading instruction: Center for Open Science.

Cain, K., \& Oakhill, J. (2006). Profiles of children with specific reading comprehension difficulties. British Journal of Educational Psychology, 76(4), 683-696 .doi:10.1348/000709905x67610

Carreker, S., \& Birsh, J. (2011). Multisensory teaching of basic skills activity book. Baltimore: MD: Brookes.

Clark, M. (2013). Is there one best method of teaching reading? What is the evidence? Education Journal, 156, 14-16.

Colenbrander, D., Ricketts, J., \& Breadmore, H. L. (2018). Early Identification of Dyslexia: Understanding the Issues. Lang Speech Hear Serv Sch, 49(4), 817-828. doi:10.1044/2018_lshss-dyslc-18-0007

Creswell, J. (2013). Qualitative Inquiry \& Research Design: Choosing Among Five Approaches (3 ed.): SAGE Publications.

Ehri, C., Nunes, R., Stahl, A., \& Willows, M. (2001). Systematic Phonics Instruction Helps Students Learn to Read: Evidence from the National Reading Panel's Meta-Analysis. Review of Educational Research, 71(3), 393-447. doi:10.3102/00346543071003393

Ehri, L. C., Nunes, S. R., Stahl, S. A., \& Willows, D. M. (2001). Systematic phonics instruction helps students learn to read: Evidence from the National Reading Panel's metaanalysis. Review of Educational Research, 71, 393-447.

Eide, B., \& Eide, F. (2011). The dyslexic advantage: Unlocking the hidden potential of the dyslexic brain (1 ed.): New York: Hudson Street Press.

Erdely-Bartha, A. (2017). Preventing the learning disabilities by using multisensorial methods, the processing program "VAKT" V-visual, Aauditory, K-kinestetic, T-tactile. Revista Română de Terapia Tulburărilor de Limbaj şi Comunicare, 3(1), 33-47. doi:10.26744/rrttlc.2017.3.1.05

Evans, A., \& Hornberger, H. (2005). No child left behind: repealing and Unpeeling federal language education policy in the united states. Language Policy, 4(1), 87-106. doi:10.1007/s10993-004-6566-2

Everatt, J., \& Reid, G. (2009). Dyslexia: an overview of recent research. The Routledge Companion to Dyslexia. NY: Routledge.

Farrell, M. (2013). The Effective Teacher's Guide to Dyslexia and other Learning Difficulties (Learning Disabilities): Routledge.

Gillam, S. L., \& Gillam, R. B. (2014). Improving clinical services: Be aware of fuzzy connections between principles and strategies. Language, Speech, and Hearing Services in Schools, 45(2), 137-144 . 
Goswami, U. (2008). Principles of learning, implications for teaching: A cognitive neuroscience perspective. Journal of Philosophy of

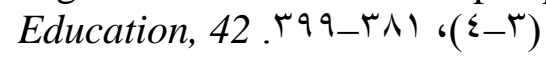

Goswami, U. (Ed.) (2013). Educational neuroscience: Bridging the gulf between basic research and implications for practice (Vol. 315-334): 2.

Griffiths, Y., \& Stuart, M. (2013). Reviewing evidence- based practice for pupils with dyslexia and literacy difficulties. Journal of Research in Reading, 36(1), 96-116.

Halladay, J., \& Duke, N. (2013). Informational Text and the Common Core State Standards: International Reading Association.

Hatcher, P. (2006). Phonological awareness and reading intervention. The Practitioner's Handbook: Dyslexia Speech and Language (2nd Edition ed.): West Sussex: Whurr Publishers.

Hatcher, P., Hulme, C., \& Snowling, M. (2004). Explicit phoneme training combined with phonic reading instruction helps young children at risk of reading failure. Journal of child psychology and psychiatry, and allied disciplines, 45, 338-358. doi:10.1111/j.1469-7610.2004.00225.x

Hebert, M., Kearns, D. M., Hayes, J. B., Bazis, P., \& Cooper, S. (2018). Why Children With Dyslexia Struggle With Writing and How to Help Them. Language, Speech, and Hearing Services in Schools, 49(4), 843-863. doi:https://doi.org/10.1044/2018_LSHSS-DYSLC-18-0024

Kang, E. Y., \& Shin, M. (2019). The Contributions of Reading Fluency and Decoding to Reading Comprehension for Struggling Readers in the Fourth Grade. Read Writ $Q$, 35(3), 179-192. doi:10.1080/10573569.2018.1521758

King, W. M., Giess, S. A., \& Lombardino, L. J. (2007). Subtyping of children with developmental dyslexia via bootstrap aggregated clustering and the gap statistic: comparison with the double-deficit hypothesis. Int $J$ Lang Commun Disord, 42(1), 77-95. doi:10.1080/13682820600806680

Langenburg, D. (2000). Testimony before the U.S. Senate Appropriations Committee's Subcommittee on Labor, Health \& Human Services, and Education. Retrieved from National Reading Panel, National Institute of Child Health and Human Development :

Layes, S., Lalonde, R., \& Rebaï, M. (2014). Reading Speed and Phonological Awareness Deficits Among Arabic-Speaking Children with Dyslexia. Dyslexia (Chichester, England), 21(1), 80-95. doi:10.1002/dys.1491

Lee, G., Sullivan, K., \& Gupta, A. (2011). Dynamics of No Child Left Behind Policy Impacting Reading Education Practices in Kindergarten in the United States of America. International Journal of Child Care and Education Policy, 5(2), 21-31. doi:10.1007/2288-6729-5-2-21 
Liptak, E. (2016). IDA Moves Beyond Matrix. Retrieved from https://dyslexiaida.org/update-on-idas-matrix/

Lonigan, C. J., Burgess, S. R., \& Anthony, J. (2000). Development of emergent literacy and early reading skills in preschool children: Evidence from a latent-variable longitudinal study. Developmental Psychology, 36, 596613. doi:10.1037//0012-1649.36.5.596

McCulley, L. V., Katz, S., \& Vaughn, S. (2013). Reading instruction and students with learning disabilities. Advances in Special Education, 25, 19-43.

McIntyre, E., \& Hulan, N. (2013). Research-based, culturally responsive reading practice in elementary classrooms: A yearlong study. Literacy Research and Instruction, 52(1), 28-51 .

Mitchell, D., \& Sutherland, D. (2020). What Really Works in Special and Inclusive Education: Using Evidence-Based Teaching Strategies (3rd ed.): Routledge.

Moats, L., Carreker, S., Davis, R., Meisel, P., Spear-Swerling, L., \& Wilson, B. (2014). The International Dyslexia Association (IDA) Knowledge and Practice Standards for Teachers of Reading .

Morrow, L. M., Gambrell, L. B., \& Duke, N. K. (2011). Best practices in literacy instruction. New York, NY: Guilford Press.

O’Brien, B ‘.Mohamed, M., Yussof, N., \& Ng, S. (2018). The phonological awareness relation to early reading in English for three groups of simultaneous bilingual children. Reading and Writing. doi:10.1007/s11145-018-9890-1

Ott, P. (1997). How to Detect and Manage Dyslexia: A Reference and Resource Manual. Oxford: Heinemann.

Phajane, H. (2014). Introducing Beginning Reading Using Phonics Approach. Mediterranean Journal of Social Sciences. doi:10.5901/mjss.2014.v5n10p477

Prasetyaningrum, S., \& Faradila, A. (2018). Application of VAKT Methods (Visual, Auditory, Kinestetic, and Tactile) to Improve The Ability Reading for Mild Mental Retardation. Advances in Social Science, Education and Humanities Research (ASSEHR), 4th ASEAN Conference on Psychology, Counselling, and Humanities (ACPCH 2018), 304, 379-385.

Prasetyaningrum, S., \& Faradila, A. (2019). Application of VAKT Methods (Visual, Auditory, Kinestetic, and Tactile) to Improve The Ability Reading for Mild Mental Retardation. Paper presented at the Proceedings of the $\varepsilon$ th ASEAN Conference on Psychology, Counselling, and Humanities (ACPCH 2018). http://dx.doi.org/10.2991/acpch-18.2019.91 
Ramus, F. (2004). Neurobiology of dyslexia: A reinterpretation of the data. Trends in Neurosciences, 27(12), 720-726 .

Ransby, M. J \& ‘.Swanson, H. L. (2003). Reading comprehension skills of young adults with childhood diagnoses of dyslexia. J Learn Disabil, 36(6), 538-555. doi:10.1177/00222194030360060501

Rasinski, T., Rikli, A., \& Johnston, S. (2009). Reading Fluency: More Than Automaticity? More Than a Concern for the Primary Grades? Literacy Research and Instruction, 48(4), 350-361. doi:10.1080/19388070802468715

Schiff, R., \& Calif, S. (2007). Role of Phonological and Morphological Awareness in L2 Oral Word Reading. Language Learning, 57(2), 271298. doi:10.1111/j.1467-9922.2007.00409.x

Schiff, R., \& Joshi, R. M. (2017). Introduction to Special Issue: Spelling and Morphology in Different Orthographies among Readers with and without Dyslexia. Dyslexia (Chichester, England), 23(4), 31 r r r doi:10.1002/dys. 1573

Shaywitz, S. (2003). Overcoming Dyslexia: A Straight-forward Guide for Families and Teachers: Vintage Books, New York.

Shaywitz, S. E., \& Shaywitz, B. A. (2007). The Neurobiology of Reading and Dyslexia. The ASHA Leader, 12 . r. $r$. (Ir) doi:10.1044/leader.ftr7.12122007.20

Shaywitz, S. E., \& Shaywitz, B. A. (2008). Paying attention to reading: the neurobiology of reading and dyslexia. Dev Psychopathol, 20(4), 13291349. doi:10.1017/s0954579408000631

Slavin, R. E., Lake, C., Chambers, B., Cheung, A., \& Davis, S. (2009). Effective reading programs for the elementary grades: A best-evidence synthesis. Review of Educational Research, 79(4), 1391-1466 .

Snowling, M. J. (2007). Reading Development and Dyslexia: Blackwell Publishers Ltd.

Solis, M., Ciullo, S., Vaughn, S., Pyle, N., Hassaram, B., \& Leroux, A. (2012). Reading comprehension interventions for middle school students with learning disabilities: A synthesis of 30 years of research. Journal of Learning Disabilities, 45(4), $327 . r \leq \cdot-$

Stage, K. A., \& Davis, A. S. (2004). Overcoming dyslexia: A new and complete science-based program for reading problems at any level. Psychology in the Schools, 42(1), 117-118. doi:10.1002/pits.20036

Strickland, D. (2013). Linking Early Literacy Research and the Common Core State Standards: International Reading Association.

Tarrasch, R., Berman, Z., \& Friedmann, N. (2016). Mindful Reading: Mindfulness Meditation Helps Keep Readers with Dyslexia and ADHD on the Lexical Track. Front Psychol, 7, 578 . doi:10.3389/fpsyg.2016.00578 
Tashakkori, A., \& Teddlie, C. (2010). Putting the Human Back in "Human Research Methodology : The Researcher in Mixed Methods Research. Journal of Mixed Methods Research, 4(4), 271-277 .

Thompson, G. (2015). Unrecognized ambiguities in validity of intervention research: an example on explicit phonics and text-centered teaching. Frontiers in Psychology, 5. doi:10.3389/fpsyg.2014.01535

Toffalini, E., Losito, N., Zamperlin, C., \& Cornoldi, C. (2018). Reading in a transparent second language with limited orality: The case of high school students with dyslexia in Latin. Dyslexia (Chichester, England), 25(1), 57-68. doi:10.1002/dys.1603

Tolman, C. (2005). Working smarter, not harder: What teachers ofreading need to know and be able to teach. Perspectives, 31, 16-23 .

Torgeson, J. K. (Ed.) (2002). Lessons learned from intervention research in reading: A way to go before we rest. London.

Turner, T., Clabough, J., \& Cole, W. (2014). Getting at the Core of the Common Core with Social Studies (Teaching and Learning Social Studies): Information Age Publishing.

Vaisman, E., \& Kahn-Horwitz, J. (2019). English foreign language teachers' linguistic knowledge, beliefs, and reported practices regarding reading and spelling instruction. Dyslexia (Chichester, England). doi:10.1002/dys. 1608

Willcutt, E. G., Boada, R., Riddle, M. W., Chhabildas, N., DeFries, J. C., \& Pennington, B. F. (2011). Colorado Learning Difficulties Questionnaire: validation of a parent-report screening measure. Psychol Assess, 23(3), 778-791. doi:10.1037/a0023290

Wu, Y., Barquero, L. A., Pickren, S. E., Barber, A. T., \& Cutting, L. E. (2020). The relationship between cognitive skills and reading comprehension of narrative and expository texts: A longitudinal study from Grade 1 to Grade 4. Learn Individ Differ, 80. doi:10.1016/j.lindif.2020.101848

Wyse, D., \& Goswami, U. (2008). Synthetic phonics and the teaching of reading. British Educational Research Journal, 34(6), 691-710. doi:10.1080/01411920802268912 